\title{
THE LEVEL OF PROINFLAMMATORY AND ANTIINFLAMMATORY CYTOKINES IN SPERM PLASMA OF FERTILE AND INFERTILE MEN
}

\author{
Hanna Maksymyuk ${ }^{1}$, Zinovij Vorobets ${ }^{2}$, Vasyl Maksymyuk ${ }^{3}$ \\ ${ }^{1}$ Department of Clinical laboratory diagnostics on FPGE of the Danylo Halytsky Lviv National Medical University \\ ${ }^{2}$ Department of Medical biology, parasitology and genetics of the Danylo Halytsky Lviv National Medical \\ University \\ ${ }^{3}$ Institute of Agriculture of the Carpathian Region
}

Maksymyuk H., Vorobets Z., Maksymyuk V. (2015), The level of proinflammatory and antiinflammatory cytokines in sperm plasma of fertile and infertile men. Health Problems of Civilization, 4 (9), p. 21-25.

Summary: The present study was carried out with the aim to evaluate the relation of the content of proinflammatory and antiinflammatory cytokines with the sperm quality indicators. The study involved 45 patients with a pathological spermogram and 15 practically healthy men. A positive correlation $(r=0.45)$ between the content of IL- 6 and the sperm concentration in the ejaculate and a negative correlation $(r=-0.42)$ of this cytokine with the number of live sperm were revealed. The concentration of IL-8 was positively correlated with sperm density $(r=0.52)$ and it was negatively correlated with the number of live sperm $(r=-0.55)$. A positive correlation between the content of IL-10 and the sperm concentration as well as the number of active forms was observed ( $r=0.45$ and 0.5 , respectively), and a negative correlation $(r=-0.7)$ was observed between the ejaculate volume and the concentration of IL-10. In the obtained ejaculates, a close positive correlation between the content of IL- 8 and IL- $6(r=0.74)$ and between the concentration of IL-10 and IL- $6(r=0.72)$ was observed. Based on the completed study, a conclusion was made that the increased level of IL- 6 and IL-8 may result in the reduction of the sperm quality, and, possibly, infertility, and that IL-10 plays an important role in improving sperm parameters.

Keywords: sperm, IL-6, IL-8, IL-10

\section{Introduction}

In the reproductive system of men and male animals, interleukins are produced by immune testis cells, interstitial cells, Sertoli cells and spermatogonia. According to the chemical structure, interleukins are low molecular peptides with different immunological activity. Binding to receptors of the target cell, they stimulate intracellular signal transduction, regulate the growth and differentiation of germ cells, reproductive, neuroendocrine and testicular functions of the tissues of genital organs. It is known that this regulation is mutual, and different cells in the reproductive system can not only produce their own cytokines, but also regulate their secretion. With the weakening of cytokine production, changes in the functioning of the reproductive system are possible, and this can lead to male infertility (Dousset et al. 1997, Diemer T. et al. 2003, Li Qian et al. 2012).

IL-6 is a multifunctional cytokine that belongs to the major mediators of the acute phase of the inflammatory response. It is found in various biological fluids and in sperm in particular. In the male reproductive system, this interleukin is produced by Sertoli cells. It was found out (Gruschwitz et al. 1996, Eggert-Kruse et al. 2001, Nandipandt et al. 2005) that the increase in the level of cytokines (IL-6 i IL-8) is associated with the development of inflammatory processes in the genital tract of men. In addition, researchers (Bookfor F.R. et al. 1994, Legue et al. 2001) found that changes in the content of IL- 6 affect spermatogenesis.

IL-8, also called a neutrophil attractant, belongs to a group of chemokines. It plays a key role in the inflammatory response, stimulating phagocytosis and bactericidal activity of neutrophils (Shimoya et al. 1993). Just like other cytokines, IL-8 is present in sperm plasma (Garcia-Velasco, Arici 1999, Furuya et al. 2003, Sanocka et al. 2003). Under conditions of normospermia, the average level of IL-8 in sperm plasma of men is significantly higher than its level in the blood (Sanocka et al. 2003). It was revealed (Koumantakis et al. 1998) that in healthy

\footnotetext{
Address for correspondence: Hanna Maksymyuk, Department of clinical laboratory diagnostics on FPGE of the Danylo Halytsky Lviv National Medical University, Pekarska st., 69, Lviv, 79010, phone: +380 066 654 5933, e-mail: hanna.maksymjuk@gmail.com

Tables: 5 Figures: 0 References: 21 Full-text PDF www.hpc.edu.pl Copyright (C) Pope John Paul II State School of Higher Education in Biała Podlaska, Sidorska 95/97, 21-500 Biała Podlaska Indexation: Index Copernicus, AGR0, ProQuest, Polish Medical Bibliography, Polish Ministry of Science and Higher Education. This is an open-access article distributed under the terms of the Creative Common Attribution Non-commercial license (http://creativecommons.org/licenses/by-nc/3.0), which permits use, distribution and reproduction in any medium, provided the original works is properly cited, the use is non-commercial and is otherwise in compliance with the license.
} 
men its contents in sperm plasma is 31.5 times higher than in the blood. Such a high difference can confirm the fact that primarily IL-8 is produced by the reproductive system (Dziadecki et al. 2010).

IL-10 was first described as a factor blocking the synthesis of cytokines that produce Th2-cells (Chuklyn, Perejaslov 2005). IL-10 models the expression of cytokines, soluble mediators and cell surface molecules by cells of the myeloid origin and are able to activate and support the immune and inflammatory response. IL-10 significantly inhibits production of IL-6, and its synthesis by monocytes in the first place is effectively blocked by IL-4 and by IL-10 itself. IL-10 plays a key role in maintaining the balance between pathological and protective processes, participating in establishing this balance (Chuklyn, Perejaslov 2005).

The aim of this study was to evaluate the diagnostic significance of the level of IL-6, IL-8 and IL-10 in sperm plasma and to establish the correlation between the content of these cytokines and the parameters of spermogram of infertile and fertile men.

\section{Materials and methods}

We studied ejaculates of 60 men, who during 2013-2014 visited the clinic for infertility. Sperm samples were obtained after 3-5 days of sexual absence. The average age of men was $33 \pm 2.26$ years.

The ejaculates were kept for 30 minutes at the room temperature, after which a standard evaluation of the secretion was performed according to the requirements (WHO). After complete liquefaction of the ejaculate, the samples were centrifuged at $600 \mathrm{~g}$ for 20 minutes. The supernatant was collected and stored at $-20^{\circ} \mathrm{C}$. The concentration of IL-6, IL-8 and IL-10 was determined using the immunoenzyme method (Stat-fax-303) according to the instructions for sets made by the company Vector-Best. The results of the study were analyzed for the volume, sperm density, sperm concentration $\left(10^{6} / \mathrm{ml}\right)$, the percentage of sperm forward movement $(a+b)$ and live sex cells, and the content of IL-6, IL-8 and IL-10. The software Microsoft Excel was used for the statistic analysis. The data groups were compared using the t-test and a correlation analysis was performed.

\section{Results and discussion}

The average age of 45 patients with a pathological spermogram made up $30.78 \pm 0.85$ years, and the average age of 15 healthy donors was $33.00 \pm 1.30$ years. Based on the analysis of normal and pathological spermograms, it was found that the volume of ejaculate in a group of donors was $3.22 \pm 0.19 \mathrm{ml}$, whereas in the infertile men the figure is slightly higher $-3.84 \pm 0.24 \mathrm{ml}(\mathrm{p}<0.05)$ (table 1). The sperm density was also higher in infertile men and was $3.07 \pm 0.45$ against $2.4 \pm 0.23 \mathrm{~mm}(\mathrm{p}<0.1)$ in fertile men.

Table 1. Indicators of spermograms of fertile and infertile men $(\mathrm{M} \pm \mathrm{m})$

\begin{tabular}{|c|c|c|}
\hline Spermogram indicators & Fertile men & Infertile men \\
\hline ejaculate volume, $\mathrm{ml}$ & $3.22 \pm 0.19$ & $3.84 \pm 0.24$ \\
\hline sperm density, $\mathrm{mm}$ & $2.4 \pm 0.23$ & $3.07 \pm 0.45$ \\
\hline sperm concentration, $\times 10^{6} / \mathrm{ml}$ & $80.80 \pm 5.45$ & $56.42 \pm 6.85$ \\
\hline sperm forward movement $(\mathrm{a}+\mathrm{b}), \%$ & $56.60 \pm 1.18$ & $41.92 \pm 3.19$ \\
\hline number of live sperm, $\%$ & $65.80 \pm 1.87$ & $42.79 \pm 3.20$ \\
\hline
\end{tabular}

The number of sperm is significantly higher in the group of healthy men $80.80 \pm 5.45 \times 10^{6} / \mathrm{ml}$ against $56.42 \pm$ $6.85 \times 10^{6} / \mathrm{ml}(\mathrm{p}<0.01)$ in the group of infertile men. The same trend was observed concerning the percentage of sperm forward movement and live sperm, which in the donor group made up $56.6 \pm 1.18 \%$ compared to infertile men $-41.92 \pm 3.19 \%(\mathrm{p}<0.001)$ and $65.8 \pm 1.87 \%$ against $42.79 \pm 3.20 \%(\mathrm{p}<0.001)$, respectively.

The content of IL-6, IL-8 and IL-10 was determined in sperm plasma of infertile and fertile men (table 2). The concentration of IL- 6 in the sperm plasma of healthy men is 6.6 times lower in comparison with the group of infertile men: $4.62 \pm 0.56$ against $30.58 \pm 4.78 \mathrm{pg} / \mathrm{ml}(\mathrm{p}<0.001)$. The same trend was observed regarding the content of IL-8: $973.92 \pm 66.10 \mathrm{pg} / \mathrm{ml}$ against $1684.45 \pm 118.78 \mathrm{pg} / \mathrm{ml}(\mathrm{p}<0.001)$. The same concentration of IL10 was higher in the group of fertile men: $14.60 \pm 1.51 \mathrm{pg} / \mathrm{ml}$, as opposed to the group of men with pathological spermogram - $10.53 \pm 1.26 \mathrm{pg} / \mathrm{ml}(\mathrm{p}<0.01)$. 
Table 2. The content of interleukins in sperm plasma $(\mathrm{M} \pm \mathrm{m})$

\begin{tabular}{|c|c|c|c|}
\hline \multirow{2}{*}{ Groups of men } & \multicolumn{2}{|c|}{ The content of interleukins, pg / ml } \\
\cline { 2 - 4 } & IL-6 & IL-8 & IL-10 \\
\hline fertile men & $4.62 \pm 0.56$ & $973.92 \pm 66.10$ & $14.60 \pm 1.51$ \\
\hline range (interval) & $3.10-6.00$ & $858.80-1206.40$ & $10.53 \pm 1.26$ \\
\hline infertile men & $30.58 \pm 4.78$ & $1684.45 \pm 118.78$ & $0.40-30.90$ \\
\hline range (interval) & $1.00-97.70$ & $736.29-3033.03$ & \\
\hline
\end{tabular}

The concentration of IL- 6 in sperm plasma of healthy men varied within the range of 3.1-6.0 pg / ml, IL-8 from 858.8 to $1206.4 \mathrm{pg} / \mathrm{ml}$ and IL-10 from $10.9-20.0 \mathrm{pg} / \mathrm{ml}$. The content of IL-6 in ejaculate plasma of men with pathological spermogram ranged from 1.00 to $97.7 \mathrm{pg} / \mathrm{ml}$. The concentration of IL-8 varied within a considerably wider range and therefore was $736.29-3033.03 \mathrm{pg} / \mathrm{ml}$. The content of IL-10 was the lowest and was within $0.40-30.9 \mathrm{pg} / \mathrm{ml}$.

The infertile men's ejaculates under study, depending on the concentration of interleukins, were divided into three groups (tables 3-5). The content of IL-6 in the first group was $6.22 \pm 0.83 \mathrm{pg} / \mathrm{ml}$, in the second group it was $19.64 \pm 1.27 \mathrm{pg} / \mathrm{ml}$ and in the third group it made up $74.06 \pm 6.81 \mathrm{pg} / \mathrm{ml}$ (table 3). Having performed a correlation analysis between the level of IL- 6 and spermogram indicators, we have found a negative correlation between the volume of ejaculate in all three groups $(r=-0.32 ;-0.21 ;-0.12)$ and a positive correlation with the sperm density in group II $(\mathrm{r}=0.3)$. There is a negative correlation between the percentage of live sperm in group I $(r=-0.42)$ and a positive correlation in groups I-III between the content of IL- 6 and the percentage of motility sperm $(\mathrm{r}=0.3 ; 0.45 ; 0.31)$. A positive correlation between the content of IL- 6 and IL-8 was found in groups I and III ( $\mathrm{r}=0.54$ and 0.47$)$ and with IL-10 in group III $(\mathrm{r}=0.45)$.

Table 3. Correlation of IL- 6 with the spermogram indicators $(M \pm m)$

\begin{tabular}{|c|c|c|c|c|c|c|}
\hline \multirow{2}{*}{ Spermogram indicators } & \multicolumn{6}{|c|}{ Ejaculate groups } \\
\hline & I & $\mathbf{r}$ & II & $\mathbf{r}$ & III & $\mathbf{r}$ \\
\hline content of IL- $6, \mathrm{pkg} / \mathrm{ml}$ & $6.22 \pm 0.83$ & & $19.64 \pm 1.27$ & & $74.06 \pm 6.81$ & \\
\hline ejaculate volume, $\mathrm{ml}$ & $3.47 \pm 0.28$ & -0.32 & $4.19 \pm 0.34$ & -0.21 & $3.74 \pm 0.32$ & -0.12 \\
\hline sperm density, $\mathrm{mm}$ & $4.67 \pm 0.28$ & -0.11 & $2.82 \pm 0.31$ & 0.3 & $2.13 \pm 0.20$ & -0.27 \\
\hline sperm concentration, $10^{6} / \mathrm{ml}$ & $68.75 \pm 5.37$ & 0.37 & $59.59 \pm 5.76$ & 0.34 & $43.81 \pm 4.53$ & -0.28 \\
\hline $\begin{array}{l}\text { sperm forward movement } \\
\qquad(a+b), \%\end{array}$ & $47.9 \pm 3.54$ & 0.30 & $34.46 \pm 3.65$ & 0.45 & $44.25 \pm 4.52$ & 0.31 \\
\hline number of live sperm, $\%$ & $50.63 \pm 4.72$ & -0.42 & $40.23 \pm 4.65$ & -0.05 & $40.54 \pm 4.19$ & 0.17 \\
\hline content of IL-8, pg/ml & $1430.12 \pm 140.19$ & 0.54 & $1691.86 \pm 162.78$ & -0.12 & $1950.46 \pm 143.5$ & 0.47 \\
\hline content of IL-10, pg/ml & $8.12 \pm 0.79$ & -0.25 & $10.67 \pm 1.94$ & 0.14 & $12.43 \pm 1.81$ & 0.45 \\
\hline
\end{tabular}

The concentration of IL-8 in the first group made up $1084.36 \pm 37.49 \mathrm{pg} / \mathrm{ml}$, in the second group it was $1987.55 \pm 99.1 \mathrm{pg} / \mathrm{ml}$ and in the third group it was $2762.53 \pm 49.67 \mathrm{pg} / \mathrm{ml}$ (table 4). Using the correlation analysis, a positive relationship was found between sperm density and the content of IL-8 in group II ( $\mathrm{r}=0.52)$; a negative correlation of the concentration of IL- 8 with the number of live sperm was found in groups II and III: -0.55 and -0.32 , respectively.

Table 4. The correlation of IL-8 with the spermatogram indicators $(M \pm m)$

\begin{tabular}{|c|c|c|c|c|c|c|}
\hline \multirow{2}{*}{ Spermogram indicators } & \multicolumn{5}{|c|}{ Ejaculate groups } & r \\
\cline { 2 - 7 } & I & r & II & R & III \\
\hline content of IL-8, pkg/ml & $1084.36 \pm 37.49$ & & $1987.55 \pm 99.1$ & & $2762.53 \pm 49.67$ & \\
\hline ejaculate volume, ml & $3.94 \pm 0.32$ & -0.17 & $3.53 \pm 0.33$ & -0.14 & $3.85 \pm 0.43$ & 0.04 \\
\hline sperm density, mm & $4.05 \pm 0.35$ & -0.13 & $2.38 \pm 0.24$ & 0.52 & $2.0 \pm 0.25$ & 0.24 \\
\hline sperm concentration, $10^{6} / \mathrm{ml}$ & $66.45 \pm 6.83$ & 0.12 & $46.13 \pm 4.98$ & 0.19 & $47.2 \pm 4.54$ & -0.19 \\
\hline $\begin{array}{c}\text { sperm forward movement } \\
\text { (a+b), \% }\end{array}$ & $40.94 \pm 4.73$ & 0.24 & $41.25 \pm 3.1$ & 0.18 & $43.69 \pm 4.33$ & 0.36 \\
\hline number of live sperm, \% & $44.82 \pm 4.36$ & 0.13 & $38.57 \pm 3.19$ & -0.55 & $42.3 \pm 4.39$ & -0.32 \\
\hline content of IL-6, pg/ml & $24.8 \pm 2.17$ & 0.39 & $31.59 \pm 3.54$ & 0.07 & $42.49 \pm 4.58$ & 0.74 \\
\hline content of IL-10, pg/ml & $8.95 \pm 1.54$ & 0.1 & $11.23 \pm 1.44$ & 0.12 & $12.78 \pm 1.6$ & 0.27 \\
\hline
\end{tabular}


In group III, we recorded a positive correlation between the content of IL-8 and the number of active sperm $r=0.36$. Also, a positive correlation is observed between the content of IL- 6 and IL-8 in groups I and III ( $r=0.39$ and 0.74$)$.

The content of IL-10 in group I was $4.06 \pm 0.27 \mathrm{pg} / \mathrm{ml}$, in group II it was $9.28 \pm 0.77 \mathrm{pg} / \mathrm{ml}$ and in group III it was $23.53 \pm 1.76 \mathrm{pg} / \mathrm{ml}$ (table 5). In group II, a positive correlation between the volume of ejaculate and the content of IL-10 ( $\mathrm{r}=0.51$ ) was observed, while in group III this relationship was negative $(\mathrm{r}=-0.7)$. A strong positive correlation was recorded in group III between the sperm density and the concentration of IL-10 ( $\mathrm{r}=0.8)$. Also, a positive correlation of the content of IL-10 in respect of the sperm concentration in $1 \mathrm{ml}$ of ejaculate was found in group III $-r=0.45$. A positive correlation between IL-10 in respect of the percentage of motility sperm was observed in group II ( $\mathrm{r}=0.30)$ and in group III $(\mathrm{r}=0.5)$ the content of IL-10 in group III negatively correlated with the number of live sperm and $r=-0.39$.

Table 5. Correlation of IL-10 with the spermogram indicators $(M \pm m)$

\begin{tabular}{|c|c|c|c|c|c|c|}
\hline \multirow{2}{*}{ Spermogram indicators } & \multicolumn{6}{|c|}{ Ejaculate groups } \\
\hline & I & $\mathbf{r}$ & II & $\mathbf{R}$ & III & $\mathbf{r}$ \\
\hline content of IL-10, $\mathrm{pkg} / \mathrm{ml}$ & $4.06 \pm 0.27$ & & $9.28 \pm 0.77$ & & $23.53 \pm 1.76$ & \\
\hline ejaculate volume, $\mathrm{ml}$ & $4.04 \pm 0.41$ & -0.05 & $4.1 \pm 0.47$ & 0.51 & $3.2 \pm 0.33$ & -0.7 \\
\hline sperm density, $\mathrm{mm}$ & $3.82 \pm 0.37$ & -0.18 & $3.44 \pm 0.29$ & -0.35 & $1.5 \pm 0.16$ & 0.8 \\
\hline sperm concentration, $10^{6} / \mathrm{ml}$ & $49.65 \pm 4.63$ & 0.02 & $62.56 \pm 5.43$ & -0.06 & $57.83 \pm 5.65$ & 0.45 \\
\hline $\begin{array}{l}\text { sperm forward movement } \\
\qquad(a+b), \%\end{array}$ & $36.57 \pm 3.27$ & 0.22 & $46.43 \pm 4.73$ & 0.3 & $43.0 \pm 3.50$ & 0.5 \\
\hline number of live sperm, $\%$ & $29.75 \pm 2.34$ & -0.08 & $47.5 \pm 3.59$ & -0.08 & $52.8 \pm 5.52$ & -0.39 \\
\hline content of IL-6, $\mathrm{pkg} / \mathrm{ml}$ & $19.96 \pm 1.11$ & -0.51 & $32.87 \pm 3.55$ & 0.15 & $41.77 \pm 3.58$ & 0.72 \\
\hline content of IL-8, $\mathrm{pkg} / \mathrm{ml}$ & $1542.22 \pm 136.96$ & 0.16 & $1492.82 \pm 138.01$ & -0.09 & $2190.19 \pm 209.64$ & 0.05 \\
\hline
\end{tabular}

In group I, a negative correlation between the content of IL-10 and IL-6 ( $r=-0.51)$ was found, while in group III, this relationship was positive $(r=0.72)$.

Cytokines play a central role in physiological and pathological processes in the body, and namely they initiate an immune-inflammatory cascade and modulate a neurocrine control during reproduction. Also, the genetic factor affects the functioning of interleukins. Perhaps, they are local mediators of influence on sex hormones and are involved in the regulation of spermatogenesis (Sharkey 1998).

The present work identifies the content of pro-inflammatory (IL-6 IL-8) and anti-inflammatory (IL-10) cytokines in sperm plasma of donors and men with a pathological spermogram. IL-6 is a multifactorial cytokine contained in spermal plasma and it is produced by different cell types of the genital tract. Its level correlates with the activity of Sertoli cells. It was revealed that the concentration of IL-8 and IL- 6 in sperm plasma is markedly higher than its concentration in blood serum (Humar et al. 1999, Comhaire et al. 1994). The absolute concentration of IL-8 in sperm fluid, as compared with the content of IL-10, is also much higher. Our study showed a significantly higher level of pro-inflammatory interleukins compared with anti-inflammatory interleukin level in sperm of infertile men. Also, an increased level of IL- 6 and IL-8 in men ejaculate was found while reducing the percentage content of live forms of sex cells. It was found that the increase of the concentration of IL- 8 results in a reduction in the number of live sperm forms. This can be considered as a clinically important parameter in relation to the level of fertility. However, according to some reports (Dousset et al. 1997), IL-6 was not showing any relation with the standard parameters of the ejaculate analysis. It has been revealed (Li Quian et al. 2012) that IL- 6 and IL-8 affect the sperm activeness, but do not affect the sperm number and morphology. The high level of IL-10 is characteristic of ejaculates with a high sperm concentration and a large number of active forms. These observations are confirmed by the data (Vera et al. 2003), which showed a direct statistical correlation between IL-10 and individual sperm activeness. However, at lower concentrations of inflammatory cytokines (such as IL-10), the sperm quality deteriorates, and this reinforces the concept of the problem.

The negative correlation of pro-inflammatory cytokines with the progressive activeness and the number of active sperm confirms their role in the reduction of the sperm quality. This theory is supported by observations (Camejo et al. 2001), which revealed a relation between the level of IL-6 and sperm membranes peroxidation of infertile men. 


\section{Conclusions}

Infertile men have an increased level of IL-6 and IL-8 and a decreased concentration of IL-10. Maybe proinflammatory cytokines are involved in the development of male infertility, and the high content of IL-10 supports optimal spermogram indicators. It was found that the level of IL-8 and IL-6 is the opposite to the sperm quality, namely of the number of live sperm forms. IL-10 positively correlates with the sperm concentration and the number of their active forms, that can play an important role in improving the quality of ejaculate. Probably the measurement of these biochemical markers in patients could help in establishing the clinical diagnosis.

\section{References:}

1. Bookfor F.R., Wang D., Lin T., Nagpal M.L., Spangelo B.L. (1994), Interleukin 6 secretion from rat Leydig cells in culture. Endocrinology, 134, 2150-2155.

2. Camejo M., Segnini A., Proverbio F. (2001), Interleukin-6 in seminal plasma of infertile men amd lipid peroxidation of their sperm. Arch. Androl. 47, 97-101.

3. Comhaire F., Bosmans E., Ombelet W., Punjabi U., Schoonjans F. (1994), Cytokines in semen of normal men and of patients with andrological diseases. Am. J. Reprod. Immunol. 31, 99-103.

4. Chuklyn S.N., Perejaslov A.A. (2005), Cytokines. Liha-Press, Lviv.

5. Diemer T., Hales DB., Weidner W. (2003), Immune-endocrine interactions and Leyding cell function: the role of cytokines. Andrologia, 35, 55-63.

6. Dousset B., Hussenet F., Daudin M., Bujan L., Foliguet B., Nabet P. (1997), Seminal cytokine concentration (IL-1 beta, IL-2, IL-6, sR IL-2, sR IL-6), semen parameters and blood hormonal status in male infertility. Hum. Reprod. 12, 1476-1479.

7. Dziadecki W., Celinska A., Fracki S., Bablok L., Barcz E. (2010), Interleukin 6 and interleukin 8 concentrations in seminal plasma of male with seminogram abnormalities. Central European Journal of Immunology, 35(3), $162-167$.

8. Eggert-Kruse W., Boit R., Rohr G., Aufenanger J., Hund M., Strowitzki T. (2001), Relationship of seminal plasma interleukin (IL)-8 and IL-6 with semen quality. Hum. Reprod. 16, 3, 517-528.

9. Furuya Y., Akash T., Fuse H. (2003), Solube Fas and interleukin-6 and interleukin-8 levels in seminal plasma of infertile men. Arch. Androl. 49, 449-452.

10. Garcia-Velasco J.A., Arici A. (1999), Chemokines and human reproduction. Fertil Steril. 71, 983-993.

11. Gruschwitz M., Brezinschek R., Brezinschek H. (1996), Cytokine levels in the seminal plasma of infertile males. J. Androl. 17, 158-163.

12. Humar A., St. Louis P., Mazzulli T., McGeer A., Lipton J., Messner H., MacDonald K.S. (1999), Elevated serum cytokines are associated with cytomegalovirus infection and disease in bone marrow transplantant recipients. J. Infect. Dis. 179, 484-488.

13. Koumantakis E., Matalliotakis I., Kyriakou D., Fragouli Y., Relakis K. (1998), Increased levels of interleukin-8 in human seminal plasma. Androl. 30, 339-343.

14. Legue F., Guitton N., Brouazin-Jousseaume V., Colleu-Durel S., Nourgalieva K., Chenal C. (2001), IL-6 a key cytokine in vitro and in vivo response of Sertoli cells to external gamma irradiation. Cytokine, 16, 232-238.

15. Li Qian, Qingxi Shi, Yang Gu, Jicheng Song, Minglian Zhou, Maofang Hua (2012), The relationship between IL-17 and male infertility: semen analysis. African Journal of Microbiology Research, 6(27), 5672-5677.

16. Nandipati K.C., Pasqualotto F.F., Thomas A.J., Agarwal Jr\&A (2005), Relationship of interleukin-6 with semen characteristics and oxidative stress in vasectomy reversal patients. Andrologia, 37, 131-134.

17. Sanocka D., Jedrzejczak P., Szumala-Kakol A., Fraczek M., Kurpisz M. (2003), Male genital tract inflammation; the role of selected interleukins in regulation of pro-oxidant and antioxidant enzymatic substances in seminal plasma. J. Androl. 24, 448-455.

18. Sharkey A. (1998), Cytokines and implantation. Rev.Reprod. 3, 52-61.

19. Shimoya K., Matsuzaki N., Tsutsui T., Taniguchi T., Saji F., Tanizawa O. (1993), Detection of interleukin - 8 (IL-8) in seminal plasma and elevated IL-8 in seminal plasma of infertile patients with leukospermia. Fertil. Steril. 59, 885-888.

20. Vera O., Vasqucz LA., Munoz MG. (2003), Semen quality and presence of cytokines in seminal fluid of bull ejaculates. Theriogenology, 60, 553-558.

21. WHO laboratory manual for the examination and processing of human semen - 5th ed. (2010).

Submitted: 12.03 .2015

Accepted: 17.06.2015 